\title{
Long term persistent accumulation of CD8+ T cells in synovial fluid of rheumatoid arthritis
}

Kayo Masuko-Hongo, Taichi Sekine, Shinichiro Ueda, Tetsuji Kobata, Kazuhiko Yamamoto, Kusuki Nishioka, Tomohiro Kato

\begin{abstract}
Objective-To characterise the type and kinetics of $T$ cell clones in synovial lesions of patients with rheumatoid arthritis (RA).

Methods-Mononuclear cells from serial samples of synovial fluid (SF) and peripheral blood from nine RA patients were separated phenotypically using antibody coated magnetic beads. After mRNA preparation, reverse transcriptionpolymerase chain reaction (RT-PCR) was performed to amplify V-D(N)-J (that is, the third complementarity determining, CDR3) regions of their $T$ cell receptor beta chain genes. This was followed by single strand conformation polymorphism (SSCP) analysis to detect the clonotypes of accumulating $T$ cells. Amino acid sequences of the dominant clones were also determined.
\end{abstract}

Results-Although peripheral T cells were heterogeneous, accumulation of oligoclonal T cells was detected in SF. The predominant accumulating clone was the CD8 subset, which was persistently present in serial samples obtained over almost one year of follow up. A proportion of these cells expressed CD25 or CD45RO, or both, suggesting they are 'memory' clones.

Conclusion-The persistent presence of CD8+ $T$ cell clones in $R A$ joints indicates that they may be involved in the perpetuation of the chronic inflammatory process in $R A$ joints.

(Ann Rheum Dis 1997;56:613-621)

Although T cells are thought to be involved in the pathogenesis of rheumatoid arthritis (RA), the precise mechanisms by which these cells induce and/or perpetuate the chronic joint inflammatory process are still not well understood. To explore such mechanisms, it is important to characterise the $\mathrm{T}$ cells infiltrating into the affected joints. One such approach has been the use of monoclonal antibodies against several surface markers to analyse phenotypes of $\mathrm{T}$ cell populations. However, detection and analysis of the phenotype of accumulating $T$ cells at a clonal level in vivo have been so far difficult.

We have previously designed and tested a new $\mathrm{T}$ cell clonality analysis system of reverse transcription-polymerase chain reaction (RTPCR) followed by single strand conformation polymorphism (SSCP), using specific primers of TCR beta chain genes. ${ }^{1-5}$ The method focuses on the V-D $(\mathrm{N})-\mathrm{J}$ genes, which compose the third complementarity determining (CDR3) region, of the TCR beta chain. Using this system, we reported our findings in a series of studies analysing the RA synovium. ${ }^{14}$ Our results showed (a) oligoclonal $\mathrm{T}$ cell accumulation in RA synovial membrane and synovial fluid $(\mathrm{SF}),{ }^{1}$ (b) accumulating $\mathrm{T}$ cell clones were usually found in separate areas within the individual joint, ${ }^{4}$ and furthermore, (c) identical clones accumulated in multiple joints in the same patient (Kurokawa et al, submitted data). These findings strongly suggest the existence of a uniform and specific immune response in the RA joints. It is still not known, however, whether the detected immune responses at a $\mathrm{T}$ cell clonal level-that is, oligoclonal $\mathrm{T}$ cell accumulation - are always present in rheumatoid joints throughout the clinical course of the disease. Furthermore, the exact clones of the accumulating $T$ cells are not known.

To pursue this issue, we analysed in this study $\mathrm{T}$ cell clonality in serial samples of SF obtained from RA patients using the RT-PCRSSCP system. Our results showed long term accumulation of distinct CD8 $+\mathrm{T}$ cell clones in RA joints. In addition, a proportion of these cells expressed activation markers, CD25 or CD45RO, or both, indicating the existence of 'memory' $T$ cell clones in RA joints. Our results suggest that CD8+ $\mathrm{T}$ cell clones play a key part in the pathogenesis of the rheumatic process.

\section{Methods}

PATIENTS

Nine RA patients who satisfied the revised criteria of the American College of Rheumatology $^{6}$ were enrolled in this study. Table 1 shows the clinical features of these patients. Patients were receiving non-steroidal anti-inflammatory drugs, prednisolone (5-10 mg daily), and disease modifying antirheumatic drugs (for example, bucillamine or methotrexate, or both) as summarised in table 1 .

\section{CLINICAL SAMPLES}

Clinical samples were obtained from RA patients after informed consent at the indicated time interval(s). SF samples were obtained during therapeutic arthrocentesis of the knee joint. Peripheral blood samples were also obtained from the patients at the time of SF sampling. The blood sample was placed in a tube containing heparin and peripheral blood lymphocytes (PBL) were separated by using a
Accepted for publication 21 July 1997 
Table 1 Patients'characteristics

\begin{tabular}{|c|c|c|c|c|c|c|c|c|c|}
\hline Patient & $\begin{array}{l}\text { Age } \\
(y)\end{array}$ & Sex & $\begin{array}{l}\text { Disease } \\
\text { duration } \\
(y)\end{array}$ & $R F$ & Stage & Class & $\begin{array}{l}H L A \\
D R B 1\end{array}$ & $H L A D Q B 1$ & Treatment \\
\hline 1 & 49 & $\mathrm{~F}$ & 4 & - & 2 & 2 & ND & ND & $\begin{array}{l}\text { PSL, NSAIDs, } \\
\text { Buc }\end{array}$ \\
\hline 2 & 74 & M & 5 & - & 2 & 2 & ND & ND & $\begin{array}{l}\text { PSL, NSAIDs, } \\
\text { Buc }\end{array}$ \\
\hline 3 & 45 & $\mathrm{~F}$ & 6 & + & 2 & 2 & ND & ND & $\begin{array}{l}\text { SASP, Buc, } \\
\text { PSL }\end{array}$ \\
\hline 4 & 58 & $\mathrm{~F}$ & 4 & + & 1 & 2 & ND & ND & $\begin{array}{l}\text { PSL, NSAIDs, } \\
\text { MTX }\end{array}$ \\
\hline 5 & 48 & $\mathrm{~F}$ & 11 & + & 4 & 2 & ND & ND & PSL, NSAIDs \\
\hline 6 & 52 & $\mathrm{~F}$ & 20 & + & 3 & 2 & $01 / 1602$ & $0501 / 0502$ & PSL, NSAIDs \\
\hline 7 & 26 & $\mathrm{~F}$ & 3 & + & 1 & 2 & ND & $\mathrm{ND}$ & $\begin{array}{l}\text { PSL, NSAIDs, } \\
\text { Buc }\end{array}$ \\
\hline 8 & 65 & $\mathrm{~F}$ & 7 & + & 4 & 2 & 0405/0901 & $03032 / 0401$ & $\begin{array}{l}\text { Buc, MTX, } \\
\text { NSAIDs }\end{array}$ \\
\hline 9 & 59 & $\mathrm{~F}$ & 0.75 & - & 1 & 2 & $1501 / 0802$ & $0601 / 0602$ & $\begin{array}{l}\text { Buc, PSL, } \\
\text { NSAIDs }\end{array}$ \\
\hline
\end{tabular}

$\mathrm{RF}=$ rheumatoid factor $; \mathrm{PSL}=$ prednisolone NSAIDs $=$ non-steroidal anti-inflammatory drugs, $\mathrm{Buc}=$ bucillamine, $\mathrm{SASP}=$ salazosulphapyridine, $\mathrm{MTX}=$ methotrexate, $\mathrm{ND}=$ not determined. the attached cells were used in the following experiments as a positively selected cell population.

RNA ISOLATION, CDNA SYNTHESIS, AND PCR-SSCP ANALYSIS

The RT-PCR-SSCP method for T cell clonality analysis was performed as described previously by our laboratory. ${ }^{1-5}$ Briefly, mRNA isolated from each sample was converted to first strand cDNA using reverse transcriptase (Superscript BRL, Gaithersburg, MD) and random hexamer oligonucleotide priming (100 pmol, BRL). A similar amount of cDNA from each sample was mixed with each primer set (one of BV sense primers (BV 1-20) and a non-biotinylated BC antisense primer; sequences were previously described by Choi et al). ${ }^{7}$ PCR reaction was carried out with a Hybaid thermal reactor (Hybaid, Middlesex, UK) using dNTP and Taq DNA polymerase (Boehringer Mannheim, Mannheim, Germany) for 35 cycles $\left(94^{\circ} \mathrm{C}\right.$ for 1.5 minutes, $58^{\circ} \mathrm{C}$ for two minutes, and $72^{\circ} \mathrm{C}$ for three minutes). Amplifed DNA was diluted (1:20), heat denatured, and then electrophoresed in non-denaturing 4\% polyacrylamide gels. After electrophoresis, the DNA was transferred to Immobilon-S (Millipore, Bedford, MA). After prehybridisation, biotinylated $\mathrm{BC}$ internal probe (5'A (A,C)AA $(\mathrm{G}, \mathrm{C}) \mathrm{GTGTTCCCAC-}$ CCGAGGTCGCTGTGTT-3') was added to the membrane filter and it was then hybridised at $42^{\circ} \mathrm{C}$ for eight hours, washed, and finally exposed to $x$ ray films.

\section{DNA SEQUENCING}

A small area of the dried SSCP gel corresponding to the position of the dominant bands was cut out. After DNA extraction, a second PCR using BV and BC specific primers with enzymatic (EcoRI or Hindlll) sites was performed. After digestion, the amplified DNAs were subcloned into a plasmid vector (pBluescript II, Stratagene, La Jolla, CA) and clones were subjected to a di-deoxy DNA 
9725.f2

615

Figure 2 Dominant clonal accumulations are demonstrated in $C D 8+T$ cell subset of synovial $T$ cells. $(A)$ Results of analysis of $T$ cell clonality of peripheral blood lymphocytes (PBL) and synovial fluid T cells (SFTC) of a representative patient with rheumatoid arthritis. SFTC were examined as a whole group, CD4+ and CD8+ populations, and analysed independently. (B) Amplified DNAs from each population were electrophoresised on the same SSCP gel to provide a comparison between the groups. (C) Results of T cell clonality analyses of PBL and SFTC, with a phenotypic separation of $P B L$. 
Figure 3 A time course analysis of $T$ cell clonality in a representative patient with rheumatoid arthritis. Synovial fluid samples were obtained from the same patient within one month from the left and right knee joints and analysed for $T$ cell clonality using RT-PCR-SSCP.

sequencing (373A DNA Sequencing System, Perkin Elmer/Applied Biosystems, Foster City, CA).

\section{Results}

DISTINCT T CELL CLONALITY OF PBL AND SF IN THE SAME RA PATIENT

$\mathrm{T}$ cell clonality was analysed by RT-PCRSSCP system using TCR BV specific primers established previously in our laboratory. ${ }^{1-5}$ In this system, heterogeneous $\mathrm{T}$ cell populations with diverse sequences of CDR3 genes of TCR beta chain are displayed as a smear. On the other hand, a $\mathrm{T}$ cell clone with a single type of TCR appears as a sharp band. Thus, accumulation of a $\mathrm{T}$ cell clone with a diverse background can be detected as a sharp band on a smear. Using this method, we first compared the entire $\mathrm{T}$ cell clonality of paired PBL and SF samples obtained from each patient. Figure 1 shows a representative example of the RT-PCR-SSCP analysis of TCR BV 1-20 families. PBL showed smear patterns for ahnost all BV families, with a few distinct bands (fig 1). This indicated that the peripheral

Table 2 Relative percentage of phenotypes of $C D 8+T$ cell clone subpopulation in $R A$ synovial fluid ${ }^{\star}$

\begin{tabular}{lllllll}
\hline CD25 & \multirow{2}{*}{ CD45RO } & Patient 1 (\%) & Patient 4 (\%) & Patient 5 (\%) & Patient 9 (\%) & Mean \\
\hline+ & + & 0 & 33 & 13 & 14 & 15 \\
+ & - & 0 & 10 & 13 & 43 & 17 \\
- & + & 80 & 33 & 13 & 14 & 35 \\
- & - & 20 & 24 & 62 & 29 & 34
\end{tabular}

ॠ Dominant bands in each phenotype of T cell subpopulation were counted based on results of four RA patients and the relative percentages were calculated.
T cell population in RA patients had a heterogeneous sequence of TCR CDR3 genes. In contrast, analysis of SF $\mathrm{T}$ cells showed a number of sharp bands - that is, accumulating $\mathrm{T}$ cell clones-without restriction for particular TCR BV use (fig 1). Similar results were obtained in other RA patients (data not shown). These results indicate that $\mathrm{T}$ cell clonalities are different between PBL and SF T cells in the same RA patient. We also tried to analyse SF from OA patients. However, since lymphocytic infiltration was too low in OA samples, comparative data could not be obtained by RT-PCR-SSCP (data not shown).

PHENOTYPIC CHARACTERISATION OF ACCUMULATING T CELL CLONES IN SF

In the next step, we characterised the phenotype of accumulating $\mathrm{T}$ cell clones in SF. For this purpose, antibody coated magnetic beads were used to separate whole $\mathrm{T}$ cell population into different $\mathrm{T}$ cell subsets. This was followed by analysis of each sample by RT-PCR-SSCP. The representative example shown in figure 2 (patient no 4 ) confirmed that the PBL and SF $\mathrm{T}$ cells had different $\mathrm{T}$ cell clonalities (fig 2A). Phenotypic analysis also showed that a dominant part of the accumulating clones in $\mathrm{SF}$ resided in CD8+subpopulation (fig 2A and B). Moreover, a proportion of the $\mathrm{T}$ cell clones were found to be CD25 and/or CD45RO positive (fig 2B). Thus, seven dominant bands were identified in CD8+ population with BV 1 TCR 
Figure 4 Comparison of accumulating $T$ cell clones in synovial fluid $(S F)$ in two patients with rheumatoid arthritis at different time intervals. $(A)$ and $(B) S F T$ cell samples obtained at the indicated time intervals from two patients were individually analysed by RT-PCR-SSCP and finally electrophoresised on the same SSCP gel. (C) Two specimens of synovial membranes from the right wrist and left knee joint were obtained from another patient in 1993, followed by samples of synovial fluid from the right knee joint in 1995. Each sample was analysed independently and compared on the same SSCP gel. Arrows indicate dominantly accumulating clones.

(fig 2B, BV1, arrows). Among these, clones no $1,3,5$, and 7 were detected as CD8+, without appearing in $\mathrm{CD} 25+$ nor CD45RO+ population. On the other hand, clones no 2 and 4 were $\mathrm{CD} 8+\mathrm{CD} 25+\mathrm{CD} 45 \mathrm{RO}+$, whereas clone no 6 was CD8+CD45RO+ but CD25-. Conversely, PBL were then phenotypically separated and compared with SF. In this case, some accumulating clones were also found in the peripheral CD8+ $\mathrm{T}$ cell population. They were, however, different from the clones in SF. Also, the degree of clonality was more distinct in $\mathrm{SF}$ than in peripheral CD8+ $\mathrm{T}$ cells (fig 2C).

Analysis of another patient (no 5) showed the $\mathrm{T}$ cell clones were also predominantly $\mathrm{CD} 8+$ (fig 3). The predominance of CD8+ T cells was persistently observed in serial samples obtained from different arthritic joints in the same patient (fig 3). The number of the bands detected in four RA patients were counted and the relative percentages of each phenotypic population are shown in table 2. Although CD4+ T cells in both patients described above showed a few bands on SSCP, they appeared only obscure in the analyses of whole population, indicating the dominant clonality of $\mathrm{CD} 8+$ cells (fig $2 \mathrm{~A}, \mathrm{~B}, \mathrm{C}$ and fig 3 ).

IDENTICAL T CELL CLONES ARE PERSISTENTLY PRESENT IN SF

As the articular inflammatory process is characteristically chronic in RA, we next investigated whether the observed clonal accumulation of SF T cells is a short-term phenomenon or persistently present in RA joints. For this purpose, we determined the $\mathrm{T}$ cell clones and phenotypes in SF samples obtained at different time intervals in the same patient by electrophoresising sequential samples to a single SSCP gel. We have previously confirmed using DNA sequencing studies that the bands that migrate to an identical position on a single SSCP gel had identical CDR3 sequences of TCR beta chain and are thus identical clones. ${ }^{4}$ Our analysis showed that the dominant component of $\mathrm{T}$ cell clones in SF was identical in the same patient over a period ot several months (fig 4(A)-(C)). Furthermore, when synovial membrane samples from two different joints (obtained in December 1993) and a SF sample (April 1995) from the same patient (patient no 8) were compared (fig 4(C)), the dominant clones in SF were identical to those in the synovial membrane (fig $4(\mathrm{C})$, arrows).

We also investigated the phenotype of $\mathrm{T}$ cell clones in serial SF samples obtained from the same patient. For this part of the study, we were able to obtain sequential SF samples from three patients only in which the number of $T$ cells was sufficient for adequate phenotypic analysis. The results of analysis of these three patients are shown in figure $5(\mathrm{~A})-(\mathrm{C})$. In each patient, the majority of $\mathrm{T}$ cell clones were persistently CD8 positive. In addition, a proportion of these CD8+ clones were found to express CD25 or CD45RO, or both (fig 5(A)-(C), arrows). Furthermore, accumulation of certain dominant CD8+ clones was present in joints of both sides. In order to ascertain that these bands shown in CD8+ and CD25+/CD45RO+ populations are actually identical clones, sequences of CD25+ and $\mathrm{CD} 45 \mathrm{RO}+$ bands with the same migration pattern were determined respectively (lane 3 to 5 in BV5SI, fig 5(A)). As a result, adjacent bands in 


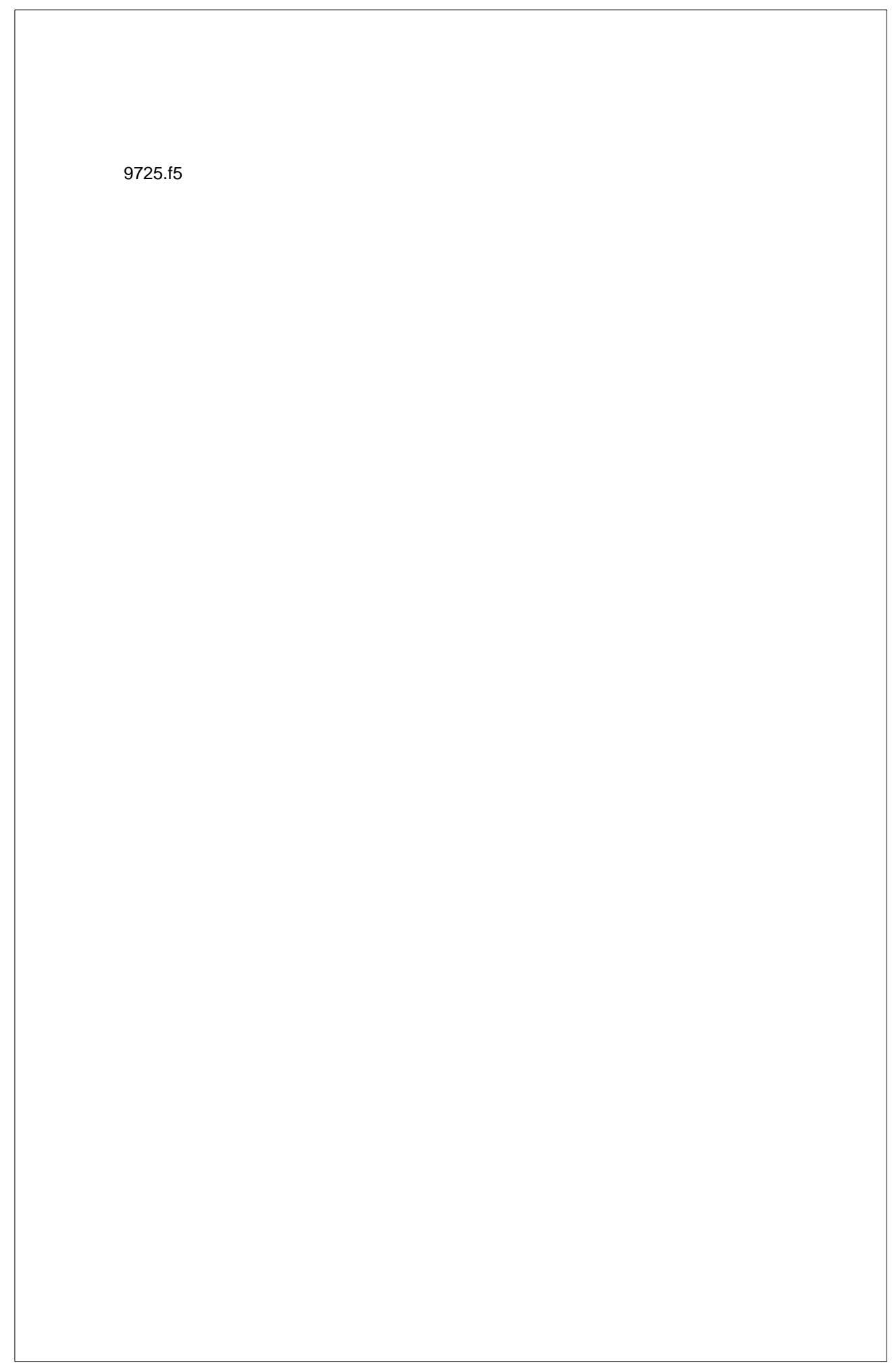

Figure 5 Serial determination of accumulated $T$ cell clones and their phenotype. (A) to (C) Serial samples of synovial fluid $T$ cells and peripheral blood lymphocyte (PBL) were obtained from three $R A$ patients and separated into $T$ cell subsets. The detected clones were compared with each other by electrophoresising to the same SSCP gels. Arrows indicate dominantly accumulating clones. The amino acid sequences of the bands are shown in table 3.

$\mathrm{CD} 25+$ and CD45RO+ were sequenced both as CAS QDRGGELF, which used BV5S I and BJ2S2 families (table 3). The results confirmed that these bands were identical clone to the band in CD8+ subset. On the other hand, PBL were heterogeneous and clones identical to SF were not detected (fig 5(A), lower panels). These find- ings strongly indicated a stable presence of distinct CD8+T cell clones in SF in multiple RA joints during the course of the study.

\section{Discussion}

Despite efforts by many investigators, no consensus has been made on the identity of 
Table 3 Deduced amino acid sequence of TCR CDR3 region of an accumulated CD8+ T cell clone in RA synovial fluid

\begin{tabular}{|c|c|c|c|c|c|c|c|c|c|c|c|c|}
\hline \multirow{2}{*}{$\begin{array}{l}\text { Clone no } 3 * \\
\text { (patient 5) }\end{array}$} & \multicolumn{12}{|l|}{$C D R 3$} \\
\hline & \multicolumn{4}{|l|}{$B V 5 S I$} & \multicolumn{3}{|l|}{$N$} & \multicolumn{5}{|l|}{$B \mathcal{F}$} \\
\hline CD8+ & $\begin{array}{l}\text { TGC } \\
\text { C }\end{array}$ & $\begin{array}{l}\text { GCC } \\
\text { A }\end{array}$ & $\begin{array}{l}\text { AGT } \\
\mathrm{S}\end{array}$ & $\begin{array}{l}\text { CAA } \\
\text { Q }\end{array}$ & $\begin{array}{l}\text { GAC } \\
\text { D }\end{array}$ & $\begin{array}{l}\text { AGG } \\
\text { R }\end{array}$ & $\begin{array}{l}\text { GGC } \\
\text { G }\end{array}$ & $\begin{array}{l}\text { GGG } \\
\text { G }\end{array}$ & $\begin{array}{l}\text { GAG } \\
\mathrm{E}\end{array}$ & $\begin{array}{l}\text { CTG } \\
\text { L }\end{array}$ & $\begin{array}{l}\text { TTT } \\
\text { F }\end{array}$ & (BJ2S2) \\
\hline CD25+ & TGC & GCC & AGT & CAA & GAC & AGG & GGC & GGG & GAG & CTG & TTT & \\
\hline & $\mathrm{C}$ & & & $\mathrm{Q}$ & & & & & & & & (BJ2S2) \\
\hline $\mathrm{CD} 45 \mathrm{RO}+$ & TGC & GCC & AGT & CAA & GAC & AGG & GGC & GGG & GAG & CTG & TTT & \\
\hline & $\mathrm{C}$ & A & $\mathrm{S}$ & Q & $\mathrm{D}$ & $\mathrm{R}$ & G & G & $\mathrm{E}$ & $\mathrm{L}$ & $\mathrm{F}$ & (BJ2S2) \\
\hline
\end{tabular}

* Corresponds to the dominant band in SSCP, as indicated in lanes 3 to 5 by an arrow in figure 5A (see figure legends).

characteristic repertoire or clonality of $\mathrm{T}$ cells in RA patients. ${ }^{89}$ One explanation for this discordance may be the methodological differences among various studies. For example, cloning or limiting dilutions to establish $\mathrm{T}$ cell clones from RA synovial lesions in vitro may not reflect the in vivo cellularity. Also, when $\mathrm{T}$ cell phenotype is determined by staining with monoclonal antibodies or immunofluorescent assay, these methods may misread the characteristics of each $\mathrm{T}$ cell clone because these techniques detect phenotype positive cells as a collective population. Another possibility is that the responsible (pathogenic) $\mathrm{T}$ cell clones may differ from one patient to another, even in the presence of one common target autoantigen. Thus, it seems necessary to investigate the characteristics of $\mathrm{T}$ cells at a clonal level in vivo, especially those $\mathrm{T}$ cell clones that accumulate within the affected lesions, as it is probable that the joint infiltrating $\mathrm{T}$ cells are important in the inflammatory process of RA. To elucidate this issue, we used in this study the RT-PCR-SSCP system for analysis of $\mathrm{T}$ cell clonality. Using this system, we examined the time course changes in T cell clonality using serial samples of synovial fluid from a group of RA patients. Our results demonstrated dominant and persistent accumulation of $\mathrm{CD} 8+\mathrm{T}$ cell clones in SF of RA patients.

Previous studies have suggested the predominance of CD4+ T cells in RA synovial lesions. ${ }^{10-13}$ However, such findings only described the number of these cells, without clarifying the presence of TCR specificity in each phenotypic populations of $T$ cells. As the number of $T$ cell clones specifically responding to antigen(s) in the synovial lesion may be very low, it is important to analyse TCR clonalities of the cells in detail. In this regard, recent studies have demonstrated differences in TCR repertoire between CD4+ and CD8+ $\mathrm{T}$ cell subsets in RA synovial lesions. ${ }^{14-16}$ On the other hand, however, the presence of clonal dominance of CD $4+{ }^{17} 18$ and CD8 $+{ }^{19-21}$ subsets in the peripheral blood has also been suggested, in addition to that in the synovial $\mathrm{T}$ cells of RA patients. For example, Fitzgerald et $a l^{20}$ reported clonal expansion of peripheral $\mathrm{T}$ cells in normal donors as well as in patients with RA. Thus, the phenomenon itself-that is, peripheral CD8+ clonal expansion-would be neither restricted to RA patients nor always related to the pathogenesis of RA. Furthermore, it is suggested that the clonally expanding CD8+ cells in the periphery are stable in RA patients and have a restricted TCR use. ${ }^{2022}$ However, the peripheral clonality may differ from that of active inflammatory sites, in which specific immune responses by $\mathrm{T}$ cells might be occurring. Considering these findings together, it seems necessary to compare the $\mathrm{T}$ cell population in SF T cells and PBL in paired samples obtained simultaneously from the same patient to establish the mechanisms producing specific $\mathrm{T}$ cell clonalities. In this study, we analysed $\mathrm{T}$ cell clonality in paired $\mathrm{SF} / \mathrm{blood}$ samples obtained from a group of RA patients, using the ability of the RT-PCR-SSCP system in detecting $\mathrm{T}$ cell clonal accumulation by examining multiple BV families at the same time. Using this system, our results showed oligoclonal accumulation of $\mathrm{T}$ cells with dominance in the RA synovial lesions rather than in the periphery. Moreover, we found that the accumulating clones were mostly CD8+ and were persistently present in the same patient throughout a long follow up period. These findings are consistent with the results of Wang et al ${ }^{2}$ who also found stable CD8+ expansion in RA.

We have previously shown that $\mathrm{T}$ cell clonal accumulation is induced after appropriate antigenic stimulation..$^{1-3}$ It may be, therefore, possible that the CD8+ clones in SF have accumulated in response to specific antigen(s) within the synovial lesions. In this regard, Hingorani et $a l^{1}$ also suggested that the chronic, oligoclonal CD8+ $\mathrm{T}$ cells might bear the 'immune history' in RA patients. As we detected identical $\mathrm{T}$ cell clones both in SF and synovial membrane (fig $4(\mathrm{C})$ ), it is probable that $S F T$ cells and synovial membrane infiltrating $\mathrm{T}$ cells, at least in part, recognise the same antigen(s).

In addition to CD4/CD8 phenotypes, the activation status of accumulated $\mathrm{T}$ cell clones in RA joints has been a matter of interest. However, though the existence of 'activated' or 'primed' $T$ cells in RA synovial lesions has been reported, ${ }^{123-25}$ most studies have so far investigated the expression of each phenotypic marker as a population while it has been difficult to analyse it at a clonal level in vivo. In this study, we first analysed the expression of activation markers on each type of accumulated $T$ cell clones in SF. We found that $\mathrm{T}$ cell clones expressing CD25 and/or CD45RO were detected more frequently in CD8+ subset, but seldom in CD4+ subset (fig 2(B), 5(A) and (B), table 2). Previous studies have suggested that $\mathrm{CD} 45 \mathrm{RO}+$ are 'antigen experienced' $\mathrm{T}$ cell population, that is, a 'memory' compartment, both in CD4+ and $\mathrm{CD} 8+$, are primed by antigen(s). ${ }^{26-30}$ Thus, it is 
possible that the accumulating CD8+CD45RO+ clones would represent a 'primed' population by specific antigen(s) in situ in the affected RA joint. The co-expression of CD25 molecule and CD45RO also suggests that these clones have been recently activated. ${ }^{28}$ Naturally, it would be necessary to investigate in the future the expression of other surface markers such as CD45RA, CD11a, CD62L, to evaluate these accumulating $\mathrm{CD} 8+\mathrm{T}$ cell clones as 'memory' clones. ${ }^{3132}$ Direct comparison of $\mathrm{T}$ cell clonality with other inflammatory arthritic diseases would be also of help. ${ }^{25}$ The putative antigen to which the CD8+ $\mathrm{T}$ cells respond to is still unknown. In this regard, the existence of $\mathrm{CD} 8+\mathrm{T}$ cells reactive to autologous B lymphoblastoid cells has been suggested in RA. ${ }^{33}$

We also examined the serial changes in $\mathrm{T}$ cells in RA in the same patient and showed the continued presence of dominant CD8 $+\mathrm{T}$ cells within the same joint over a period of about one year. Other studies have also examined the time course of $\mathrm{T}$ cells in the RA joints. ${ }^{34-37}$ However, this issue is still controversial because most studies analysed only limited BV families or a limited number of patients, or they did not use phenotypic studies of the cells. In this study, we analysed the kinetics of $T$ cells with broad range of TCR BV families in SF, separating them into CD4+/CD8+ populations, taken from a panel of RA patients. Our results suggest the persistence of some (probably CD8+) $\mathrm{T}$ cell clones, despite diversity of CD4+ $\mathrm{T}$ cell repertoire in RA SF. The relative heterogeneity of CD4+ T cell population may suggest that the immune response of $\mathrm{T}$ cells toward MHC class II restricted antigens presented on the RA synovium is dynamic, not static, and is diverse. In this regard, Goronzy and coworkers ${ }^{17}$ reported that patients with early RA possess characteristic CD4+ T cell clonal dominance in the periphery. Thus, it is possible that SF T cells may contain, during the early stages of $\mathrm{RA}$, a small proportion of pathogenic $\mathrm{T}$ cell clone(s).

In conclusion, we identified long term clonal accumulation of CD8+ $T$ cells in SF of RA patients. This finding suggests that certain mechanisms are present for local recruitment of distinct $\mathrm{CD} 8+\mathrm{T}$ cell clones in the rheumatoid joints. Our findings also imply the active involvement of CD8+ $\mathrm{T}$ cells in the perpetuation of chronic joint disease of RA.

We thank Ms Emi Niwa, Ms Kaoru Kamataki, Ms Hiroko Sasakawa, and Ms Yuka Onogi for their technical assistance and Ms Ami Wakamatsu for her secretarial support. We also thank Dr F Issa, from the Department of Medicine, University of Sydney, Sydney, Australia, for the careful reading and editing of the manuscript.

This study was supported in part by grants in aid from the Ministry of Health and Welfare, Ministry of Education, Science and Culture of Japan, and the Japan Rheumatism Foundation.

1 Yamamoto K, Sakoda H, Nakajima T, Kato T, Okubo M, Dohi $\mathrm{M}$, et al. Accumulation of multiple $\mathrm{T}$ cell clonotypes in the synovial lesions of patients with rheumatoid arthritis revealed by a novel clonality analysis. Int Immunol revealed by a nov

2 Masuko K, Kato T, Ikeda Y, Okubo M, Mizushima Y, Nishioka $\mathrm{K}$, et al. Dynamic changes of accumulated $\mathrm{T}$ cell clonotypes during antigenic stimulation in vivo and in vitro. Int Immunol 1994;6:1959-66.

3 Masuko K, Kato S, Hagihara M, Tsuchida F, Takemoto Y, et al. Stable clonal expansion of T cells induced by bone marrow transplantation. Blood 1996;87:789-99.

4 Ikeda Y, Masuko K, Nakai Y, Kato T, Hasunuma T, et al. High frequencies of identical $\mathrm{T}$ cell clonotypes in synovial tissues of rheumatoid arthritis patients suggest the occurrence of common antigen-driven immune response. Arthritis Rheum 1996;39:446-53.

5 Höger TA, Tokuyama M, Yonamine K, Hayashi $K$, a $+\mathrm{T}+\mathrm{T}$ cell clones during normal pregnancy. Eur J Immunol 1996;26:834-8.

6 Arnett FC, Edworthy SM, Bloch DA, McShane DJ, Fries JF, Cooper NS, et al. The American Rheumatism Association 1987 revised criteria for the classification of rheumatoid arthritis. Arthritis Rheum 1988;31:315-24.

7 Choi Y, Kotzin B, Herron L, Callahan J, Marrack P, Kappler J. Interaction of Staphylococcus aureus toxin "superantigens" with human T cells. Proc Natl Acad Sci USA 1989; 86:8941-5

8 Struyk L, Hawes GE, Chatila MK, Breedveld FC, Kurnick JT, van der Elsen PJ. T cell receptors in rheumatoid arthritis. Arthritis Rheum 1995;5:577-89.

9 Richardson BC. T cell receptor usage in rheumatic disease. Clin Exp Rheumatol 1992;10:271-83.

10 Goto M, Miyamoto T, Nishioka K, Uchida S. T cytotoxic and helper cells are markedly increased, and $\mathrm{T}$ suppressor and inducer cells are markedly decreased, in rheumatoid synovial fluids. Arthritis Rheum 1987;30:737-43.

11 Fox RI, Fong S, Sabharwal N, Carstens SA, Kung PC, Vauglin JH. Synovial fluid lymphocytes differ from peripheral blood lymphocytes in patients with rheumatoid arthritis. J Immunol 1982;128:351-4.

12 Hough AJ Jr. Pathology of rheumatoid arthritis and allied disorders. In: McCarty DJ, ed. Arthritis and allied disorders. 12th ed. Philadelphia: Lea \& Febiger, 1993.

13 Nakao H, Eguchi K, Kawakami A, Migita K, Otsubo T, Ueki Y, et al. Phenotypic characterization of lymphocytes infiltrating synovial tissue from patients with rheumatoid infiltrating sylyis of lymphocytes isolated from minced synovial tissue by dual immunofluorescent staining. J Rheumatol 1990;17:142-8.

14 Gudmundsson S, Ronnelid J, Karlsson-Parra A, Lysholm J, Gudbjornsson B, Widenfalk B, et al. T-cell receptor V-gene usage in synovial fluid and synovial tissue from RA patients. Scand J Immunol 1992;36:681-8.

15 Sottini A, Imberti L, Bettinardi A, Mazza C, Gorla R, Primi D. Selection of T Iymphocytes in two rheumatoid arthritis patients defines different $\mathrm{T}$-cell receptor $\mathrm{V}$ beta repertoires in $\mathrm{CD} 4+$ and $\mathrm{CD} 8+\mathrm{T}$-cell subsets. J Autoimmun 1993;6:621-37.

16 Cooper SM, Roessner KD, Naito-Hoopes M, Howard DB, Gaur LK, Budd RC. Increased usage of V $\beta 2$ and V $\beta 6$ in rheumatoid synovial fluid $\mathrm{T}$ cells. Arthritis Rheum 1994;11:1627-36.

17 Goronzy JJ, Bartz-Bazzanella P, Hu W, Jendro MC, WalserKuntz DR, Weyand CM. Dominant clonotypes in the repKuntz DR, Weyand CM. Dominant clonotypes in the repertoire of peripheral CD4+ T cells

18 Waase I, Kayser C, Carlson PJ, C, oronzy JJ, Weyand CM. Oligoclonal $\mathrm{T}$ cell proliferation in patients with rheumatoid arthritis and their unaffected siblings. Arthritis Rheum 1996;39:904-13.

19 DerSimonian H, Sugita M, Glass DN, Maier AL, Weinblatt ME, Reme T, et al. Clonal V alpha 12.1+ T cell expansions in the peripheral blood of rheumatoid arthritis patients. J Exp Med 1993;177:1623-31.

20 Fitzgerald JE, Ricalton NS, Meyre A-C, West SG, Kaplan $\mathrm{H}$, Behrendt $\mathrm{C}$, et al. Analysis of clonal CD8+ $\mathrm{T}$ cell expansions in normal individuals and patients with rheumatoid arthritis. J lmmunol 1995;154:3538-47.

21 Hingorani R, Monteiro J, Furie R, Chartash E, Navarrete C, Pergolizzi R, et al. Oligoclonality of V beta 3 TCR chains in the CD8+ $\mathrm{T}$ cell population of rheumatoid arthritis patients. J Immunol 1996;156:852-8.

22 Wang ECY, Lawson TM, Vedhara K, Moss PAH, Lehner PJ, Borysiewicz LK. CD8high+ (CD57+) T cells in patients with rheumatoid arthritis. Arthritis Rheum 1997; 40: $237-48$

23 Matthews N, Emery P, Pilling D, Akbar A, Salmon M. Subpopulations of primed $T$ helper cells in rheumatoid arthritis. Arthritis Rheum 1993;36:603-7.

24 Struyk L, Hawes GE, Dolhain RJEM, van Scherpenzeel A, Godthelp B, Breedveld FC, et al. Evidence for selective in vivo expansion of synovial tissue-infiltrating CD4+CD45RO+ T Iymphocytes on the basis of CDR3 diversity. Int Immunol 1994;6:897-907.

25 Kuryliszyn-Moskal A. Comparison of blood and synovial fluid lymphocyte subsets in rheumatoid arthritis and osteoarthritis. Clin Rheumatol 1995;14:43-50.

26 Richards SJ, Jones RA, Roberts BE, Patel D, Scott CS. Relationships between 2H4 (CD45RA) and UCHL1 (CD45RO) expression by normal blood CD4+CD8-, CD4-CD8+, CD4-CD8dim+, CD3+CD4-CD8- and 81:149-55.

27 Barclay AN, Birkeland ML, Brown MH, Beyers AD, Davis SJ, Somoza C, et al. In: The leucocyte antigen factsbook. London: Academic Press, 1993.

28 Zola H, Flego L, Macardle PJ, Donohoe PJ, Ranford J, Roberton D. The CD45RO (p180, UCHL1) marker: 
complexity of expression in peripheral blood. Cell Immunol 1992;145:175-86.

29 Okumura $M$, Fujii Y, Inada $K$, Nakahara $K$, Matsuda $H$. Both CD45RA+ and CD45RA- subpopulations of CD8+ $\mathrm{T}$ cells contain cells with high levels of lymphocyte function-associated antigen-1 expression, a phenotype of primed T cells. J Immunol 1993;150:429-37.

30 Hingorani R, Choi I-H, Akolkar P, Gulwani-Akolkar B, Pergolizzi R, Silver J, et al. Clonal predominance of $\mathrm{T}$ cell receptors with.in the CD8+CD45RO+ subset in normal human subjects. J Immunol 1993;151:5762-9.

31 Rabin RL, Roederer M, Maldonado Y, Petru A, Herzenberg LA, Herzenberg LA. Altered representation of naive and memory CD8 T cell subsets in HIV-infected children. J Clin Invest 1995;95:2054-60.

32 Roederer M, Dubs JG, Anderson MT, Raju PA, Herzenberg LA, Herzenberg LA. CD8 naive T cell counts decrease progressively in HIV-infected adults. J Clin Invest 1995;95: 2061-6.
33 David-Ameline J, Lim A, Davodeau F, Peyrat MA, Berthelol $\mathrm{JM}$, Semana G, et al. Selection of T cells reactive against autologous B lymphoblastoid cells during chronic rheuautologous B lymphoblastoid cells during chron
matoid arthritis. J Immunol 1996;157:4697-706

34 Alam A, Lambert N, Lulé J, Coppin H, Mazières B, de Préval C, et al. Persistence of dominant T cell clones in synovial tissues during rheumatoid arthritis. J Immunol 1996;156: 3480-5.

35 Ali Khazaei H, Lunardi C, So AK. CD4 T cells in the rheumatoid joint are oligoclonally activated and change during the course of disease. Ann Rheum Dis 1995;54:314-7.

36 Grom AA, Thompson SD, Luyrink L, Passo M, Choi E, Glass DN. Dominant T cell-receptor $\beta$ chain variable region V $\beta 14+$ clones in juvenile rheumatoid arthritis. Proc Natl Acad Sci USA 1993;90:11104-8.

$37 \mathrm{Li} \mathrm{Y}$, Sun G-R, Tumang JR, Crow MK, Friedman SM. CDR 3 motifs shared by oligoclonal rheumatoid arthritis synovial T cells. J Clin Invest 1994;94:2525-31.

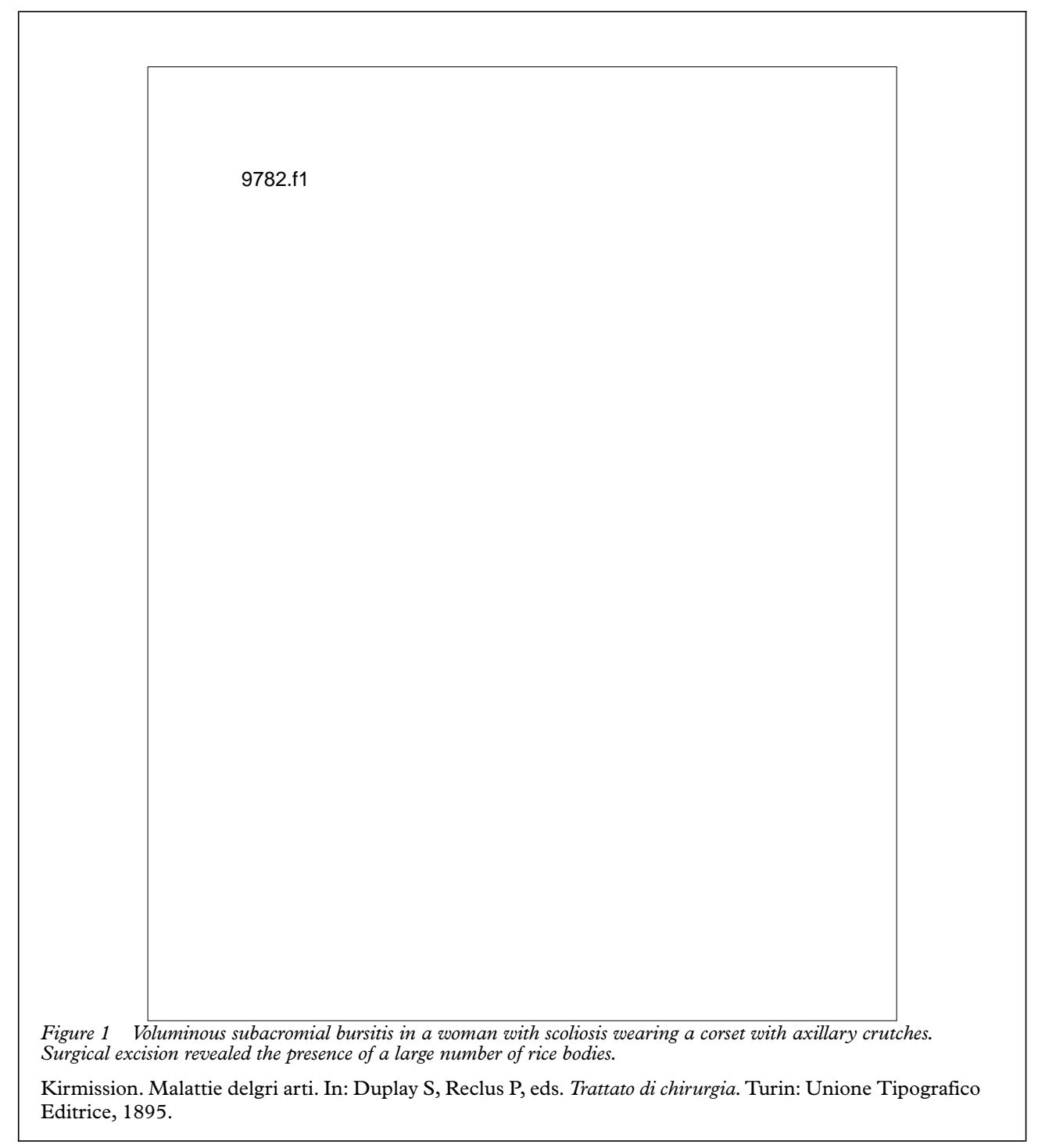

